\title{
Some Aspects of Nutrient Analysis of Seed, Pulp and Oil of Baobab (Adansonia digitata L.)
}

\author{
G.O. Oyeleke ${ }^{1}$, M.A. Salam ${ }^{2}$ and R.O Adetoro ${ }^{3}$ \\ ${ }^{1,2}$ Science Laboratory Technology Department, Osun State Polytechnic, Iree, Nigeria. \\ ${ }^{3}$ Chemistry Department, Osun State College of Education, Ila-Orangun, Nigeria.
}

\begin{abstract}
Proximate, mineral and selected physicochemical characteristics of baobab (Adansonia digitata) seed, pulp and seed-oil were determined using standard analytical methods. The proximate composition (\%) of the seed and pulp were as follows; moisture ( $3.8 \pm 0.2$ and $11.2 \pm 0.2)$, protein $(19.5 \pm 0.5$ and $3.5 \pm 0.1)$, fat (13.4 \pm 0.1 and $0.4 \pm 0.1)$, ash (3.1 \pm 0.1 and $4.5 \pm 0.5)$, crude fibre $(15.6 \pm 0.5$ and $6.1 \pm 0.1)$ and carbohydrate (44.6 and 74.3). Baobab seed, pulp and seed-oil are good source of macro and micro nutrients with potassium $(K)$ being the most predominant element with magnessiun $(\mathrm{Mg})$, calcium $(\mathrm{Ca})$ and phosphorus $(\mathrm{P})$ also present in appreciable quantities. The physicochemical properties also revealed slightly acidic $P^{H}$ for the pulp $(5.6 \pm$ $0.2)$ and oil $(6.1 \pm 0.1)$ while the seed was alkaline $(8.2 \pm 0.1)$. From the soluble solid content, the pulp contains more sugar than the seed while the titrable acidity of the oil with $3.51 \pm 0.10$ is higher than $0.65 \pm 0.04$ of the pulp. The saponification, iodine and acid values of the oil were $218.41 \pm 0.20 \mathrm{mgKOH} / \mathrm{g}, 92.10 \pm 1.50 \mathrm{mgI} / 100 \mathrm{~g}$ and $6.52 \pm 0.02 \mathrm{mgKOH} / \mathrm{g}$ respectively while the refractive index and specific gravity were $1.498 \pm 0.002$ and $0.928 \pm 0.001$. The results presented here established the edibility of the pulp, seed and oil as well as a pointer to its industrial usage.
\end{abstract}

Keywords: Proximate, mineral, physicochemical, saponification, pulp, oil, seed, edible.

\section{Introduction}

Seed, pulp and seed-oil are important components of plants that could be explored to meet up with the food demand of the world's increasing population.

Baobab tree (Adansonia digitata) is a member of the Bombacaceae family which consists of around 20 genera and 180 species. It is a deciduous tree that was originally located in Africa but can still be found in large quantities in America, India, Malaysia [1] and hosts of other countries. It is tolerant to high temperature and long spans of drought. It is also known as "monkey bread tree". The baobab fruit which is harvested by collecting from the trees or the ground consists of large seeds embedded in dry acidic pulp and shell [2]. Baobab pulp is used in juice production while the seed and the seed oil are used in soup preparation as flavouring agents.

Nutritional analysis of baobab fruit pulp has shown that it is an excellent source of pectin, calcium, vitamin $\mathrm{C}$ and iron. Its vitamin $\mathrm{C}$ content has been compared with oranges and found that it is about three times higher (46mg/100 compared to $150-499 \mathrm{mg} / 100 \mathrm{~g}$ ) [3] while Wilkinson, [4] also showed that the vitamin C levels ranged from $74-163 \mathrm{mg} / 100 \mathrm{~g}$ and all parts of the baobab tree are reported to have medicinal properties.

Research attention towards increasing the usefulness of plant protein source for food use includes peanut [5], fluted pumpkin [6], cashew nut [7] and yam beans [8].

The knowledge of nutrition value of local dishes, soup ingredients and local foodstuffs is necessary in order to encourage the increase cultivation and consumption [9].

This research work focused on the nutrient and physicochemical compositions of the pulp, seed and seed -oil of baobab in order to expand the scope of knowledge on its full utilization.

\section{Materials and Methods}

\subsection{Materials}

\subsection{Collection and Preparation of Samples}

The baobab fruits used for this work were collected from a co research fellow from Osun State Polytechnic, Iree, Nigeria.

The pulp was separated from the seed manually. The pulp obtained was kept for further analysis while the seeds were sun dried for two weeks, ground, passed through a $2 \mathrm{~mm}$ sieve and stored in air tight bags ready for further analysis. 
Some Aspects of Nutrient Analysis of Seed, Pulp and Oil of Baobab (Adansonia digitata L.)

2.3 Methods

\subsubsection{Proximate and Elemental Compositions}

The moisture, protein, crude fibre, ash, fat and total carbohydrate (determined by difference) contents of the pulp and seed of baobab as well as the mineral contents were determined by the methods of A.O.A.C, [10].

\subsubsection{Selected Physicochemical Properties of Pulp, Seed and Oil}

Titrable acidity and total soluble solids (Brix) of the pulp and seed were determined according to the methods described by Onimawo, [11]. The $\mathrm{P}^{\mathrm{H}}$ of the samples were done using Philips Harris $\mathrm{P}^{\mathrm{H}}$ meter.

The acid value, saponification and the iodine values were done by methods outlined by AOAC, [10].

The specific gravity $\left(25^{\circ} \mathrm{C}\right)$ and refractive index $\left(\right.$ at $\left.26^{\circ} \mathrm{C}\right)$ were determined by using universal hydrometer and Abbe refractometer

\subsection{Results}

\section{Results and Discussion}

Table 1: Proximate Composition of baobab Pulp and Seed (\%)

\begin{tabular}{lrr}
\hline Parameter & Seed \pm S.D & Pulp \pm S.D \\
\hline Moisture & $3.8 \pm 0.2$ & $11.2 \pm 0.2$ \\
Ash & $3.1 \pm 0.1$ & $4.5 \pm 0.1$ \\
Fat & $13.4 \pm 0.5$ & $0.4 \pm 0.1$ \\
Crude fibre & $15.6 \pm 0.5$ & $6.1 \pm 0.1$ \\
Crude protein & $19.5 \pm 0.5$ & $3.5 \pm 0.1$ \\
Carbohydrate & $44.6 \pm 0.2$ & $74.3 \pm 0.1$ \\
\hline
\end{tabular}

All results are average of duplicate determinations $\underline{ \pm}$ standard deviation (S.D.).

Table 2: Mineral Composition of baobab Pulp, Seed and Seed-oil (mg/100g)

\begin{tabular}{lrrr}
\hline Parameter & Pulp \pm S.D & Seed \pm S.D & \multicolumn{1}{c}{ Oil \pm S.D } \\
\hline $\mathrm{Na}$ & $35.10 \pm 0.50$ & $40.72 \pm 0.20$ & $25.15 \pm 0.10$ \\
$\mathrm{~K}$ & $1410.35 \pm 0.25$ & $875.15 \pm 0.05$ & $506.20 \pm 0.15$ \\
$\mathrm{Mg}$ & $69.12 \pm 0.02$ & $315.17 \pm 0.05$ & $116.10 \pm 0.20$ \\
$\mathrm{Ca}$ & $78.18 \pm 0.15$ & $521.10 \pm 0.25$ & $70.50 \pm 0.20$ \\
$\mathrm{P}$ & $105.20 \pm 0.10$ & $125.50 \pm 0.50$ & $87.75 \pm 0.05$ \\
$\mathrm{Fe}$ & $5.85 \pm 0.20$ & $10.12 \pm 0.10$ & $3.50 \pm 0.10$ \\
\hline
\end{tabular}

All results are average of duplicate determinations \pm standard deviation (S.D.).

Table 3: Selected Physicochemical Properties of baobab Pulp, Seed and Oil

\begin{tabular}{cccc}
\hline Parameter & Pulp \pm S.D & Seed \pm S.D & Oil \pm S.D \\
\hline $\mathrm{P}^{\mathrm{H}}$ & $5.60 \pm 0.20$ & $8.15 \pm 0.10$ & $6.12 \pm 0.50$ \\
Soluble solid (brix) & $15.0 \pm 0.1$ & $1.5 \pm 0.4$ & $\mathrm{ND}$ \\
Titrable acidity $(\%)$ & $0.68 \pm 0.04$ & $3.51 \pm 0.10$ & $\mathrm{ND}$ \\
Refractive index $\left(26^{\circ} \mathrm{C}\right)$ & $\mathrm{ND}$ & $\mathrm{ND}$ & $1.498 \pm 0.002$ \\
Specific gravity $\left(25^{\circ} \mathrm{C}\right)$ & $\mathrm{ND}$ & $\mathrm{ND}$ & $0.928 \pm 0.001$ \\
Saponification value* $^{*}$ & $\mathrm{ND}$ & $\mathrm{ND}$ & $218.41 \pm 0.20$ \\
Acid value* $^{*}$ & $\mathrm{ND}$ & $\mathrm{ND}$ & $6.52 \pm 0.02$ \\
Iodine value** & $\mathrm{ND}$ & $\mathrm{ND}$ & $92.10 \pm 1.50$ \\
\hline
\end{tabular}

All results are average of duplicate determinations + standard deviation (S.D.).

$*(\mathrm{mgKOH} / \mathrm{g}), * *\left(\mathrm{mgI}_{2} / 100 \mathrm{~g}\right)$ and $\mathrm{ND}$ (not determined).

\subsection{Discussion}

The proximate composition of the seed and pulp is shown in Table 1. The moisture content was $3.8 \pm$ $0.2 \%$ in the seed while the pulp was found to have $11.2 \pm 0.2 \%$ moisture content. The moisture content of the 
Some Aspects of Nutrient Analysis of Seed, Pulp and Oil of Baobab (Adansonia digitata L.)

seed is low compared to $5.8 \pm 0.04 \%$ in groundnut [9] and $4.6 \%$ for Citrullus lanatus seed [12] respectively. The moisture content of the pulp is lower than $81 \pm 0.72 \%$ reported for Anonna muricata [11].

The protein content of the seed was found to be $19.5 \pm 0.5 \%$. This value is lower than $38.61 \pm 0.07 \%$ and $23.4 \%$ reported for groundnut and $C$. lanatus seeds $[9,12]$ while the $3.5 \pm 0.1 \%$ protein for the pulp was found to be in line with $3.2 \pm 0.1 \%$ reported for it by Magdi, [2].

The values of $13.4 \pm 0.1 \%$ fat, $3.1 \pm 0.1 \%$ ash and $15.6 \pm 0.5 \%$ crude fibre were in line with that of baobab seed. These values were however lower than $31.30 \%$ fat but higher than $2.02 \%$ ash and $2.12 \%$ crude fibre for fluted pumpkin [6].

The values for fat, ash and crude fibre contents of the pulp with $0.4 \pm 0.1 \%, 4.5 \pm 0.5 \%$ and $6.1 \%$ respectively showed some levels of closeness to those of baobab pulp [2]. The values were lower than $1.29 \pm$ $0.01 \%$ fat, $14.12 \pm 0.02 \%$ ash and higher than $1.88 \pm 0.01 \%$ crude fibre reported for unripe pulp of Carica papaya [13].

The carbohydrate contents of $44.6 \pm 0.2 \%$ in the seed and $74.3 \pm 0.1 \%$ in the pulp showed that baobab seed and pulp can be categorized as carbohydrate rich food. The carbohydrate content of the seed is comparable to $47 \%$ reported for A. muricata [11] and higher than $1.81 \pm 0.02 \%$ for groundnut [9]

Table 2 showed the mineral composition of baobab pulp, seed and oil extract. Generally, all the three parts revealed a fair deal of being a cheap source of nutritive elements with potassium being the predominant element. The seed contain higher amount of all the mineral elements relative to the pulp and seed oil except in potassium where the pulp has the highest concentration.

The seed oil followed those of the seed closely in mineral element composition. Minerals are important in the diet because they serve as cofactors for many physiologic and metabolic functions and in their absence, clinical deficiencies may occur [6]. $\mathrm{Na} / \mathrm{K}$ and $\mathrm{Ca} / \mathrm{P}$ ratios are also of medical importance especially in blood clotting and in reducing high blood pressure.

Table 3 showed some physicochemical properties of the seed, pulp and oil of baobab.The $\mathrm{P}^{\mathrm{H}}$ of $5.60 \pm$ 0.20 for the pulp indicates that it is acidic and the value is higher than that of 4.56 reported for A. muricata [11]. The $\mathrm{P}^{\mathrm{H}}$ of 6.12 of the oil is an indication of slightly acidic condition. The soluble sugar (brix) of $15.0 \pm 0.1$ and $1.5 \pm 0.4$ for pulp and seed showed that the pulp contained more sugar compared to the seed and therefore the pulp will be useful for wine production. The titrable acidity of the pulp and the seed of baobab were found to be $0.68 \pm 0.04 \%$ and $3.51 \pm 0.10 \%$ respectively.

The refractive index $\left(\right.$ at $26^{\circ} \mathrm{C}$ ) and specific gravity $\left(\right.$ at $\left.25^{\circ} \mathrm{C}\right)$ were found to be $1.498 \pm 0.002$ and $0.928 \pm 0.001$ respectively. The values were similar to that reported by Magdi [2] for baobab and also within the range found for vegetable oils. The refractive index of $1.498 \pm 0.02$ does not fall within the range of $1.475-1.485$ for drying oils.

Saponification value of $218.41 \pm 0.02 \mathrm{mgKOH} / \mathrm{g}$ for the oil was higher than $137 \mathrm{mgKOH} / \mathrm{g}$ reported for cashew nut oil [7] but lower than $232.81 \mathrm{mgKOH} / \mathrm{g}$ for palm kernel oil [14]. The high saponification value suggests that the oil may be suitable for soap making. The iodine value of $92.10 \pm 1.50 \mathrm{mgI}_{2} / 100 \mathrm{~g}$ for the oil showed that it contain low degree of unsaturation and can therefore be classified as non-drying edible oil because $80-100 \mathrm{~g} / 100 \mathrm{~g}$ iodine has been suggested for most edible oils [15].

The high saponification and low iodine values is a pointer to the stability of the oil [2]. The acid value of $6.52 \pm 0.02 \mathrm{mgKOH} / \mathrm{g}$ was found to be higher than $4.279 \mathrm{mgKOH} / \mathrm{g}$ reported for soyabean by Akanni et al, [16] and lower than $10.7 \mathrm{mgKOH} / \mathrm{g}$ for cashew nut seed [7].

\section{Conclusion}

The results of this research showed that baobab pulp, seed and oil are of high economic value in terms of protein, fat and energy contents. They are also good and cheap source of macro and micro elements. The physicochemical properties of the oil indicated that it is non-drying and edible. Industrially, the oil may be useful in small, medium and large scale for soap, cosmetic and candle making.

\section{Recommendation}

Further work should be carried out on the amino and fatty acids characteristics of the pulp, seed and oil of baobab to expand its nutritional potentials. 


\section{References}

[1] M. Sidibie and J.T. Williams, Baobab: Adansonia digitata. International Centre for Underutilized Crops, 2002, Southampton, U.K

[2] A.O. Magdi, Chemical and Nutrient Analysis of Baobab (Adansonia digitata) Fruit and Seed Protein Solubility. Plant Food for Human Nutrition 59, 2004, 29-33.

[3] S. Manfredini, S. Vertuani, E. Braccoli and V. Buzzoni, Antioxidant Capacity of Adansonia digitata Fruit, Pulp and Leaves. Acta Phytotherapeutical 2, 2002, 2-7.

[4] Wilkinson,J.A. Baobab Dried Fruit Pulp.Novel Food Applications, 2006, http://www.acnfp.gov.uk/assess//

[5] E.H. Ahmed and C.T. Young, Composition, Nutrition and Flavour of Peanut. American Peanut Research and Education Society, Yoakum, Texas. 1982, Pp. 655-687.

[6] C. Agatemor, Fluted Pumpkin (Telfairia occidentalis Hook F.) Seed: A Nutritional Assessments. EJEAFche. Vol.6, 2007, 17871793.

[7] T.F. Akinhanmi, V.N. Atasie and P.O. Akintokun, Chemical Composition and Physicochemical Properties of Cashewnut (Anarcardium occidentalis) Oil and Cashewnut Shell Liquid. J. Agric., Food \& Environ. Sci. Vol. 2 Issue 1, $2008,1-12$.

[8] D.O. Edem, C.I. Amugo and O.U. Eka, Chemical Composition of Yam beans (Sphenostylis sternocarpa). Tropical Science 59, $1990,59-63$

[9] V.N. Atasie, T.F. Akinhanmi, and C.C. Ojiodu, Proximate Analysis and Physicochemical Properties of Groundnut (Arachis hypogea L). Pak. J. of Nutr. 8(2), 2009, 194-197.

[10] A.O.A.C., Official Methods of Analysis. Association of Analytical Chemists. $18^{\text {th }}$ Edition, 2005, Washington, D.C.

[11] I.A. Onimawo, Proximate Composition and Selected Physicochemical Properties of the Seed, Pulp and Oil of Sour Sop (Anonna muricata). Plant Food for Human Nutrition 57, 2002, 165-171.

[12] G.C. Ojieh, O.M. Oluba, Y.R. Ogunlowo, K.E. Adebisi, G.O. Eidangbe and R.T. Orole, Compositional Studies of Citrullus lanatus (Egusi melon) Seed. The Internet Journal of Nutrition and Wellness Vol.6 No1, 2008.

[13] O.I. Oloyede, Chemical Profile of Unripe Pulp of Carica papaya. Pak. J. Nutr. 4(6), 2005, 379-381.

[14] V.N. Atasie and T.F. Akinhanmi, Extraction, Compositional Studies and Physicochemical Characteristics of Palm Kernel Oil. Pak. J. of Nutr. 8(6), 2009, 800-803.

[15] D. Pearson, Chemical Analysis of Food ( $8^{\text {th }}$ edn.), 1981, London, Church Hill, Livingstone.

[16] M.S. Akanni, A.S. Adekunle and E.A. Oluyemi, Physicochemical Properties of Some Non-conventional Oil seeds. J. Food Technol. $3,2001,177-181$. 